Archived version from NCDOCKS Institutional Repository http://libres.uncg.edu/ir/asu/

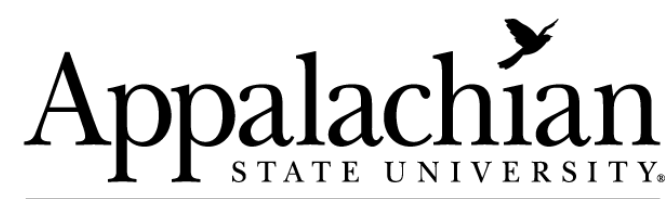 \\ B O O NE, NORTH CAROLINA
}

\section{Individualized Water Source As An Indicator Of Attitudes About Water Management And Conservation In Humid Regions}

By: Kristan Cockerill, Peter A. Groothuis, Tanga McDaniel Mohr \& Courtney Cooper

\begin{abstract}
Public perceptions about water quantity and water as a common pool resource are understudied in humid regions. As water demand increases, the need to more closely manage water, even in humid areas, will increase, requiring better understanding how people perceive their water supply, how they view paying for water conservation and how water user characteristics influence attitudes. A survey finds correlations between utilizing an individual water source (e.g. well or spring) and attitudes toward water management and conservation. Compared to respondents with a shared water source, those with an individual source believe they are segregated from regional water concerns. They are less willing to pay for water management or conservation measures and less supportive of any government intervention in water management. These results suggest that planners and water managers may face resistance to conservation policies or any policy based on the idea of water as a common pool resource.
\end{abstract}

Kristan Cockerill, Peter A. Groothuis, Tanga McDaniel Mohr \& Courtney Cooper (2015) "Individualized Water Source As An Indicator Of Attitudes About Water Management And Conservation In Humid Regions" Journal of Environmental Planning and Management Vol. 59 issue 8 pp. 1341-1359 Version of Record Available from (www.tandfonline.com) 


\section{Introduction}

Both popular and academic media report that water quantity is becoming a serious global concern, even in humid regions, as the population continues to grow and climate change alters current precipitation patterns (O’Gorman and Schneider 2009; Seager, Tzanova, and Nakamura 2009). Changes in water availability will require shifts in water management approaches in many places. Despite this news, there remains a dearth of information on public understanding of water issues and attitudes toward water quantity management and water conservation in humid regions. Understanding the specific conditions and potentially geographically unique public perceptions about water is relevant to developing appropriate management approaches (Boyer, Adams, and Borisova 2014). Further review of the small pool of research that is available on knowledge levels, concern and attitudes about water resources in humid areas will help to establish the basis for this study.

Existing data suggest a general lack of interest or concern about local water supplies in humid regions of the US. For example, participants in a 2003 focus group in Georgia reported skepticism about the seriousness of a recent drought and believed that there was enough water to meet needs (Responsive Management 2003). Public surveys in the 
South, Midwest and Northwest have found that respondents do not perceive a serious water quantity problem in the areas where they live (Borisova et al. 2013; Evans et al. 2011; Morton, Brown, and Leiting 2007; Mahler et al. 2004). In the moist Pacific Northwest, $62 \%$ of survey respondents said that water quantity was not or probably not a problem in their community (Mahler et al. 2004).

The lack of expressed concern regarding the potential for water scarcity may be related to low levels of knowledge about water systems and water supplies. Studies consistently show a lack of water literacy among students of all ages (Ewing and Mills 1994; Shepardson et al. 2007; Covitt, Gunckel, and Anderson 2009) Existing research pertaining to environmental knowledge finds that the average adult in the US knows little about water resources or processes (Coyle 2005). Further, public reaction to water shortages often reflects a lack of understanding about water and how it works (Smakhtin and Schipper, 2008). Cockerill (2010) found that attendees at community water education programs frequently relied on misconceptions about the hydrologic cycle and did not understand that water sources (e.g. groundwater and surface water) in a region may be connected hydrologically.

Attitudes pertaining to personal and public responsibility and behavior regarding water are associated with these low knowledge levels. Focus group participants in Georgia believed that industry and agriculture contribute more to water quantity problems than individuals, and they expressed a lack of appreciation that the collective actions of homeowners can have an impact on water quantity (Responsive Management 2003). Delorme, Hagen and Stout (2003) report similar findings in central Florida, where focus group participants were reluctant to acknowledge their role in creating water issues. People generally lack an accurate sense of how much water they use on a daily basis (Coyle 2005; Cockerill 2010; Noga and Wolbring 2013).

In assessing government's role in managing water, the Georgia focus group participants reported distrust of state government to regulate/enforce water conservation measures (Responsive Management 2003). Noga and Wolbring (2013) asked respondents to picture a full glass of water and note whether they perceived that water as a commodity, a natural resource, a private resource, a public resource or a human right. Relevant to our study, respondents who viewed the glass of water as a private resource were more likely to say that management is a local or individual concern and less likely to see a need for conservation.

Although there are few studies focused explicitly on pricing for water quantity, the existing research shows mixed responses to how people view paying for access to water and water conservation programs for domestic water use in both humid and arid regions. Mahler, Simmons and Sorensen (2005) found a lack of support for taxes to ensure conservation and water quality in the Pacific Northwest, while Georgia residents supported using prices to encourage conservation (Responsive Management 2003). Survey respondents in Texas did not support pricing as a conservation tool (Pumphrey, Edwards, and Becker 2008). Noga and Wolbring (2013) found mixed and contradictory attitudes toward pricing. Although their sample size is too small to offer definitive results, some respondents supported using price to encourage conservation, but most opposed charging more for water, and almost half opposed water restrictions. In open comments, several of Noga and Wolbring's respondents indicated that water should be free when abundant. At the same time, $38 \%$ reported a willingness to pay "As much as is necessary to maintain a secure water supply" for their household. A national survey in the US found that $63 \%$ of American voters are "willing to pay a little more each month to upgrade our water system" (ITT survey 2012). In California, 51\% of survey respondents 
favored a proposal to address long-term water access and restore the Sacramento River delta. When told that this would cost $\$ 25$ billion, however, only 36\% supported the project (Boxall 2013).

Overlying this data on attitudes and perceptions are geographic characteristics, including distinctions between urban and rural domestic water users. There is some evidence of distinctions between rural and urban residents' attitudes about water scarcity and management in the southeastern US. Specifically, urban residents seem to express more concern about water quantity issues than rural residents (Evans et al. 2011, Borisova and Adams 2010). Regarding attitudes about paying for water management or conservation, we found no studies focused on humid regions that compared urban and rural residents. In a semi-arid region of Texas, however, Pumphrey, Edwards, and Becker (2008) found no significant differences between urban and rural resident attitudes toward conservation approaches, including pricing. This study was designed to explore the understudied topic of attitudes toward water quantity management and conservation in domestic settings in a humid region. More specifically, it focused on comparing urban and rural residents. Our work relies on a policy context of water as a common pool resource (CRP) and subsequent issues of attitudes toward economic drivers and government roles in water management.

\subsection{Water as a common pool resource}

The existing data on perceptions about water quantity management and conservation are relevant to exploring water as a common pool resource. The two defining characteristics of CPRs are that they are (i) rival (one person's use subtracts from what is available to others) and (ii) non-excludable (it is difficult or costly to prevent someone from benefiting from the resource). As noted by Adams et al. (2003), knowledge of, and assumptions about, a CPR influence how policies for managing that resource are shaped. For instance, conflicts over specific resource uses can arise from different understandings of empirical evidence (e.g., historical weather events) and local laws. The consequences of conflicting priorities between various parties depend on the scope of what the authors call 'cognitive conflicts'. That is, "policy conflict arises because differences in knowledge and understanding between stakeholders frame their perceptions of resource use problems, as well as possible solutions to these problems" (Adams et al. 2003, 1916).

Economic and field experiments have uncovered norms that are associated with improving CPR use. Ostrom et al. (1999) survey early literature on the topic and discuss the importance of reciprocity as a basis for building reputations and nurturing trust. Norms may be easier to maintain in situations where objectives are shared and deviations are easily monitored and sanctioned (e.g. small farmers sharing a water source or fishermen in a small village). Without a shared vision of appropriate resource use, there is the potential to catalyze and encourage what Hardin (1968) described as the "tragedy of the commons" wherein the resource is depleted as users consider only their own marginal benefit of additional consumption.

A challenge for water management is to understand and accept the reality of water as a CPR. As the data on households' knowledge suggest, users do not always understand or accept that their use subtracts from what is available to others. Additionally, one method of 'excluding' users or limiting use of a scarce resource is via pricing mechanisms. Being an essential element for life, it is not feasible to exclude individuals from water use, but there is evidence that, under some conditions, pricing can positively influence conservation efforts (Kenney et al. 2008; Sohn 2011; Zetland 2011). Moreover, water 
prices may affect not only how much water is used, but also how water is used. Water use for drinking and cooking may not change much as price increases, but outdoor use may fall substantially. Zetland (2011) reports the price elasticity of demand for domestic consumption ranges from -0.2 to -0.4 for indoor uses, but from -0.7 to -1.2 for outdoor uses. ${ }^{1}$ Thus, a $10 \%$ increase in water rates would reduce outdoor consumption by two to three times more than indoor consumption. The corollary is that lower prices (and zero prices) can lead to what some categorize as luxury uses, such as swimming pools and bigger, greener lawns.

Municipal water is typically priced, but in many rural areas only a small fraction of households pay a unit price for water. Without this signal of water as a CPR, rural residents may perceive water quantity and its management needs differently than more urban residents. More specifically, individuals with a self-supplied source (i.e. spring, individual well or shared well) may fail to appreciate the interconnectedness of their water source to other users. As population grows, this disconnect could affect the resource regionally. Therefore, in comparing urban and rural attitudes, this study focused more explicitly on ascertaining if and how an individual's water source (e.g. a municipal supply or an individual well) influenced attitudes about water quantity management and conservation in a humid area.

\subsection{Study area characteristics}

The study area includes two counties, Ashe and Watauga, in western North Carolina. Located in the southern Appalachian Mountains, elevation varies from 762 to $1676 \mathrm{~m}$. This region is classified as temperate rain forest and, although the terrain influences precipitation locally, rainfall averages between 100 and $150 \mathrm{~cm}$ per year (Gaffin and Hotz n.d.) and snowfall totals routinely reach $130 \mathrm{~cm}$ annually (Ray's Weather Center n.d.). The headwaters of four large watersheds (Watauga, New/Kanawha, Catawba, YadkinPee Dee) flow from these counties into three different states (USEPA 2014). This is a mountainous region with a fractured bedrock groundwater system.

North Carolina is primarily a riparian rights state, so property owners have the right to use surface water on their property. In the study area counties, groundwater quantity is not regulated nor measured. This region experienced serious drought conditions in 2002-2003, 2007-2008 and 2010. During the 2007 drought, the state of North Carolina identified 30 municipalities at risk for running out of water, including one in Watauga County (High Country Council of Governments 2010). Although data on groundwater usage is not available, anecdotal evidence shared with the authors indicates that some wells in these counties did go dry during the 2007-2008 drought.

While there are urban centers, this is largely a rural region. Watauga County includes a total population of about 52,000. The county population consists of four incorporated towns, ranging in population from 192 people to 17,000 people, as well as 11 unincorporated communities. Additionally, there is a state university in Watauga County with a student population of about 16,000 students, thereby raising the effective population of the largest town to more than 30,000 people. Ashe County's total population is about 27,000 including three incorporated towns with populations ranging from 158 people to 1600 people and 17 unincorporated communities (US Census 2010). The majority of residents in both counties rely on self-supplied water sources (i.e. individual wells, shared wells or springs) to serve their household needs.

This region is characterized as being poorer than the rest of North Carolina. The median household income in the state is $\$ 45,215$ while the median income for Ashe 
County residents is $\$ 33,656$ and $\$ 33,148$ for citizens in Watauga County (US Census 2014). Additionally, about $20 \%$ of the Ashe County population and $32 \%$ of Watauga County is classified as impoverished compared to an $18 \%$ statewide poverty rate.

These counties are also considered politically conservative and anti-government. Additionally, social and political relations have been marked historically by a distinction between urban and rural populations (Williams 2002). In Ashe County, 42\% of registered voters are Republican, 33\% are Democrat and the remainder is Libertarian or Unaffiliated according to 2014 records. In Watauga County, 33\% are registered Republicans, 28\% Democrat and 39\% Unaffiliated (NC State Board of Elections 2014). The urban-rural divide was evidenced in the 2012 presidential election results, with the largest municipality in the two counties supporting Barack Obama (Democrat) and the remainder of both counties supporting Mitt Romney (Republican) (NC State Board of Elections 2014).

\section{Methods and sample representativeness}

A test survey was developed in 2012 and administered in the Town of Boone, the largest town in the broader study area, and this generated 129 responses that were used to revise several of the survey questions and survey structure. Additionally, a group of 12 students at Appalachian State University served as a focus group that took the survey and provided feedback. The revised survey included questions focused on attitudes toward water availability and conservation measures; the role of government in water management; and willingness to pay for management and conservation measures, including a contingent valuation scenario question. This survey of 51 questions, including demographic questions, was mailed in May 2013 to a random sample of 3000 residents in either Watauga or Ashe County. The surveying protocol included a primary mailing, a post card reminder and a second mailing to all non-respondents of the first wave. The survey closed in July 2013 with 714 responses from the 2413 useable addresses for a response rate of $30 \%$. Survey results were entered into SPSS for analysis. The results included 194 surveys with additional qualitative comments. These comments were transcribed into Excel and coded to align with the primary survey topics of perceptions of water availability and conservation practices; the role of government in water management; and willingness to pay for conservation measures.

Basic demographic features of the respondents were calculated and then compared to US Census data. The survey results showed an average respondent age of 61 years, a 56\% male sample and an average annual income of $\$ 62,000$. Reported education levels for both counties included $24 \%$ with a high school degree or less, $28 \%$ with some college and $48 \%$ with a Bachelor's Degree or higher. Comparing this sample to US Census data from the targeted counties, these respondents tend to be older, slightly more educated and earn a higher income than the general population in these counties. In addition, $50 \%$ of respondents indicated that their ancestors lived in this region, 97\% reported being white and $92 \%$ were homeowners. According to the US Census Bureau (2014), more than $95 \%$ of the population in both counties is white and $78 \%$ of Ashe county residents and $55 \%$ of Watauga county residents are homeowners.

A final demographic component of the survey that is highly pertinent to this study asked respondents to report their household water source. Results show that $52 \%$ utilize an individual well, 12\% an individual spring, 19\% share a well and $17 \%$ rely on a municipal water supply. In Watauga and Ashe Counties, 36\% and 19\%, respectively, of the population is actually served by a municipal (public) supply while the remainder access a self-supplied source of some kind (Kenney et al. 2009; HCCOG 2010). The 


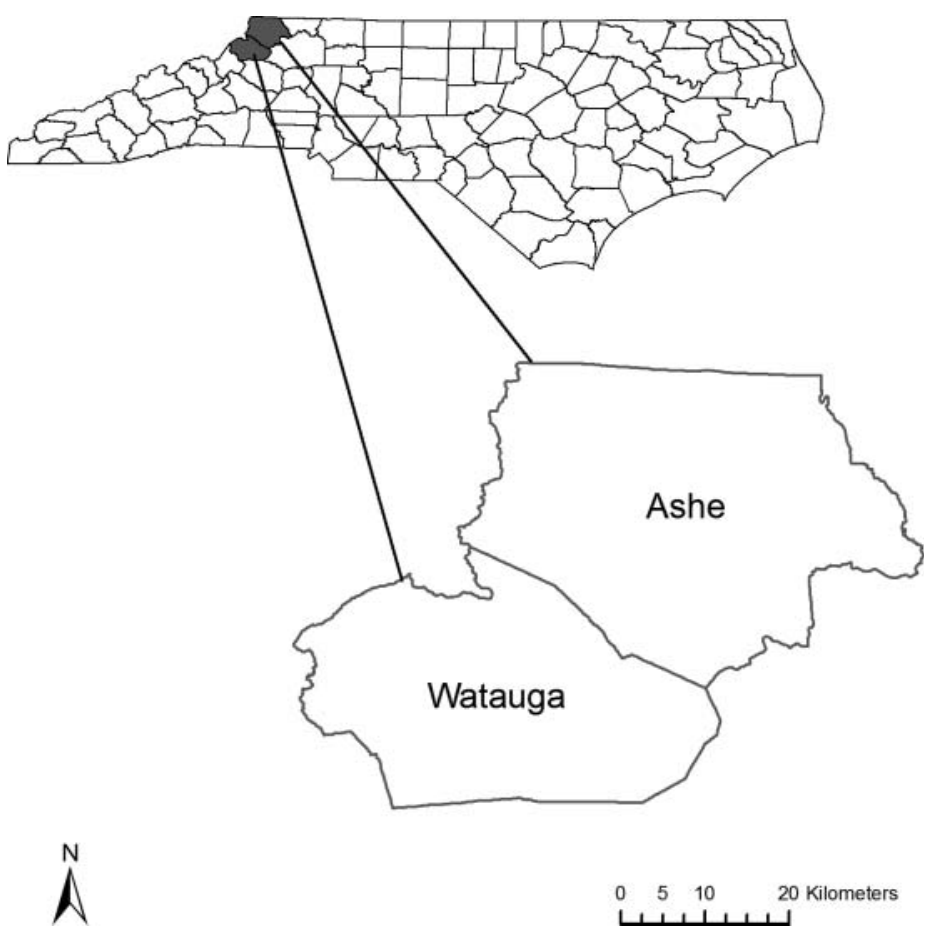

Figure 1. Study Area of Watauga and Ashe Counties, North Carolina, USA.

available data do not further delineate self-supplied sources into springs and individual or shared wells for these counties. Figure 1 provides a map of the study area.

\section{Results and analysis}

The general results from 13 attitudinal statements offer mixed messages on preferred options for water management (Table 1). For example, there is support for spending public money to acquire new water sources (statement 5) but a one-time fee on water during drought is not supported (statement 11). A majority are concerned that drought will limit water availability (statement 13) and support limiting growth to address scarcity (statement 3), but the majority also express a preference for any water restrictions to be voluntary rather than mandatory (statement 2). There is, however, no equivocating in how these respondents feel about the government role in water management: $73 \%$ disagree or strongly disagree that the state should have authority over water supplies and 50\% say that local government should not have that authority (statements 9 and 10). This differs from Stoutenborough and Vedlitz (2014) who found support for government management in a national survey, which suggests that there are attitudinal differences across geographic regions.

\subsection{Water source preferences, demographics and attitudes}

Parsing these data by household water source reveals distinctions among those who rely on a municipal supply or a shared well compared to those with an individual well or a spring. First, except those with a shared well, the majority of respondents would keep their current 
Table 1. Responses for all attitudinal questions. Scale is $1-4$ with 1 strongly disagree (SD); 2 disagree (D); 3 agree (A); and 4 strongly agree (SA).

\begin{tabular}{lccccc}
\hline Statement & Mean & StdDev & D/SD & A/SA & DK \\
\hline $\begin{array}{l}\text { 1. Water conservation is an issue that I have thought about } \\
\text { frequently in the past year }(n=702)\end{array}$ & 2.9 & 0.833 & $27 \%$ & $66 \%$ & $7 \%$ \\
2. Household water restrictions should be voluntary rather & 3.1 & 0.866 & $19 \%$ & $77 \%$ & $5 \%$ \\
than mandated by the government $(n=702)$ & & & & & \\
3. Community growth should be limited to manage water & 2.9 & 0.866 & $25 \%$ & $68 \%$ & $7 \%$ \\
scarcity $(n=696)$ \\
4. I am satisfied that my current supply provides sufficient \\
water for my use $(n=705)$
\end{tabular}

water source even if offered the opportunity to change. Respondents with individual wells or springs are extremely likely to prefer their existing source (Table 2). For those who say that they would prefer a different source, individual wells were most preferred.

For those who prefer an individualized water source, there may be a belief that such a source is preferable because it offers more individual control over how the supply is managed. It may also reflect a perception of reduced cost, as those currently on a municipal supply receive regular water bills, while those on wells or springs do not. There may also be latent concerns about water quality and a perception that wells and/or springs are 'better.' Those on shared wells may suffer from the 'worst of all worlds' in that they are responsible for managing their water source, but not as individuals; they must directly deal with others in managing the source. Those on a shared well may, in fact, best recognize the CPR nature of water and find it uncomfortable. In contrast, those on a municipal supply have no direct management responsibility; they simply pay a bill. Municipal water users are likely aware of their dependence upon others to ensure a 
Table 2. Cross tabulation of respondents self-reported water supply source and responses to the survey question: "If all of the following sources were equally available to you for your household supply which would you prefer?"

\begin{tabular}{lcccc}
\hline & \multicolumn{4}{c}{ Water supply preferred* } \\
\cline { 2 - 5 } & Municipal & Shared well & Individual well & Spring \\
\hline Water supply have & & & & \\
Municipal & $59 \%$ & $2 \%$ & $22 \%$ & $13 \%$ \\
Individual well & $9 \%$ & $1 \%$ & $74 \%$ & $14 \%$ \\
Shared well & $22 \%$ & $25 \%$ & $45 \%$ & $5 \%$ \\
Spring & $6 \%$ & $1 \%$ & $14 \%$ & $77 \%$ \\
\hline
\end{tabular}

Note: chi-square ${ }^{*} p<.01$.

consistent, clean water supply but they do not experience the direct interactions, including potential conflicts, with others in managing that supply.

Differences in general perceptions of water management are also apparent between the individual source and shared water source groups within results from several of the attitudinal questions (Table 3). Relevant to managing a CPR, 90\% of those on a municipal supply and $75 \%$ of those with shared wells say that water should be metered to know how much is used. This may reflect a fear of the 'free-rider' problem that can allow some individuals to benefit from the resource without paying for it or contributing to its management. Knowing how much water individual households use through metering can help ensure fair usage among all users. Although a majority of all respondents disagree with paying an extra fee during drought, the groups with the highest number of responses in agreement were from those with a municipal supply or a shared well. Again, this may reflect an understanding and appreciation that the water supply has multiple users and that all users should 'share the pain' of dealing with a reduced supply. Respondents with individualized water sources (i.e. a well or spring) are less likely to support metering, spending public money or allowing local public official authority over water supplies. This reinforces the idea that there is a sense of control and their language demonstrates that among these respondents there clearly is a sentiment that water is a private resource. The individual water holders are also the most confident that their existing water source will provide for all of their needs and least likely to support paying additional fees during a drought. Among the qualitative comments, 31 people explicitly noted using an individualized source. Many of these respondents subsequently concluded that this individualism segregated them from the management or conservation issues featured in the survey. Sample responses include:

\footnotetext{
"My own situation (w/a private well) puts my household and me at a distance from many of the controversies associated w/ water supply. But I am still concerned about this issue and sympathetic w/ a conservation approach."

"While I have a private spring box I believe that water conservation is important to everyone including myself and others who have a spring for water usage. I believe water usage is on the rise and freshwater availability is on the decline."

"It would have been easier to answer some of these questions if it stated that they applied to municipal water, private wells on private property or both. Private wells where no municipal water is available should be considered differently."
} 
Table 3. Cross tabulations of responses to attitudinal questions by water source: municipal supply, shared well, individual well or spring. Question scale included strongly agree (SA), agree (A), disagree (D), strongly disagree (SD) and do not know (DK).

\begin{tabular}{|c|c|c|c|c|}
\hline Statement & Municipal & Shared & Individual & Spring \\
\hline \multirow[t]{5}{*}{ 2. conservation voluntary* } & $25 \% \mathrm{SA}$ & $37 \%$ SA & $39 \% \mathrm{SA}$ & $44 \% \mathrm{SA}$ \\
\hline & $39 \% \mathrm{~A}$ & $37 \% \mathrm{~A}$ & $41 \% \mathrm{~A}$ & $38 \% \mathrm{~A}$ \\
\hline & $20 \% \mathrm{D}$ & $16 \% \mathrm{D}$ & $12 \% \mathrm{D}$ & $4 \% \mathrm{D}$ \\
\hline & $9 \% \mathrm{SD}$ & $5 \% \mathrm{SD}$ & $5 \% \mathrm{SD}$ & $6 \% \mathrm{SD}$ \\
\hline & $6 \% \mathrm{DK}$ & $5 \% \mathrm{DK}$ & $3 \% \mathrm{DK}$ & $7 \% \mathrm{DK}$ \\
\hline \multirow[t]{5}{*}{ 4. sufficient water** } & $35 \% \mathrm{SA}$ & $37 \%$ SA & $52 \% \mathrm{SA}$ & $57 \%$ SA \\
\hline & $59 \% \mathrm{~A}$ & $55 \% \mathrm{~A}$ & $47 \% \mathrm{~A}$ & $37 \% \mathrm{~A}$ \\
\hline & $3 \% \mathrm{D}$ & $4 \% \mathrm{D}$ & $1 \% \mathrm{D}$ & $2 \% \mathrm{D}$ \\
\hline & $3 \% \mathrm{SD}$ & $1 \% \mathrm{SD}$ & $0 \% \mathrm{SD}$ & $4 \% \mathrm{SD}$ \\
\hline & $1 \% \mathrm{DK}$ & $2 \% \mathrm{DK}$ & $1 \% \mathrm{DK}$ & $0 \% \mathrm{DK}$ \\
\hline \multirow[t]{5}{*}{ 5. public money* } & $24 \% \mathrm{SA}$ & $23 \% \mathrm{SA}$ & $16 \% \mathrm{SA}$ & $10 \% \mathrm{SA}$ \\
\hline & $57 \% \mathrm{~A}$ & $47 \% \mathrm{~A}$ & $49 \% \mathrm{~A}$ & $46 \% \mathrm{~A}$ \\
\hline & $8 \% \mathrm{D}$ & $16 \% \mathrm{D}$ & $17 \% \mathrm{D}$ & $22 \% \mathrm{D}$ \\
\hline & $5 \% \mathrm{SD}$ & $5 \% \mathrm{SD}$ & $9 \% \mathrm{SD}$ & $5 \% \mathrm{SD}$ \\
\hline & $6 \% \mathrm{DK}$ & $9 \% \mathrm{DK}$ & $10 \% \mathrm{DK}$ & $17 \% \mathrm{DK}$ \\
\hline \multirow[t]{5}{*}{ 7. meter ${ }^{* *}$} & $34 \% \mathrm{SA}$ & $21 \% \mathrm{SA}$ & $11 \% \mathrm{SA}$ & $10 \% \mathrm{SA}$ \\
\hline & $56 \% \mathrm{~A}$ & $54 \% \mathrm{~A}$ & $45 \% \mathrm{~A}$ & $31 \% \mathrm{~A}$ \\
\hline & $3 \% \mathrm{D}$ & $12 \% \mathrm{D}$ & $26 \% \mathrm{D}$ & $35 \% \mathrm{D}$ \\
\hline & $4 \% \mathrm{SD}$ & $3 \% \mathrm{SD}$ & $8 \% \mathrm{SD}$ & $10 \% \mathrm{SD}$ \\
\hline & $3 \% \mathrm{DK}$ & $10 \% \mathrm{DK}$ & $10 \% \mathrm{DK}$ & $14 \% \mathrm{DK}$ \\
\hline \multirow[t]{5}{*}{ 9. local public officials* } & $7 \% \mathrm{SA}$ & $9 \% \mathrm{SA}$ & $6 \% \mathrm{SA}$ & $1 \% \mathrm{SA}$ \\
\hline & $46 \% \mathrm{~A}$ & $36 \% \mathrm{~A}$ & $31 \% \mathrm{~A}$ & $20 \% \mathrm{~A}$ \\
\hline & $29 \% \mathrm{D}$ & $29 \% \mathrm{D}$ & $32 \% \mathrm{D}$ & $35 \% \mathrm{D}$ \\
\hline & $9 \% \mathrm{SD}$ & $14 \% \mathrm{SD}$ & $22 \% \mathrm{SD}$ & $26 \% \mathrm{SD}$ \\
\hline & $9 \% \mathrm{DK}$ & $12 \% \mathrm{DK}$ & $10 \% \mathrm{DK}$ & $11 \% \mathrm{DK}$ \\
\hline \multirow[t]{5}{*}{ 11. drought pay ${ }^{* *}$} & $9 \% \mathrm{SA}$ & $5 \% \mathrm{SA}$ & $2 \% \mathrm{SA}$ & $0 \% \mathrm{SA}$ \\
\hline & $33 \% \mathrm{~A}$ & $31 \% \mathrm{~A}$ & $17 \% \mathrm{~A}$ & $14 \% \mathrm{~A}$ \\
\hline & $31 \% \mathrm{D}$ & $34 \% \mathrm{D}$ & $38 \% \mathrm{D}$ & $25 \% \mathrm{D}$ \\
\hline & $21 \% \mathrm{SD}$ & $24 \% \mathrm{SD}$ & $34 \% \mathrm{SD}$ & $16 \% \mathrm{SD}$ \\
\hline & $6 \% \mathrm{DK}$ & $6 \% \mathrm{DK}$ & $9 \% \mathrm{DK}$ & $15 \% \mathrm{DK}$ \\
\hline
\end{tabular}

Note: Chi-square ${ }^{*} \mathrm{p}=.015^{* *} \mathrm{p}=.001$

"I was concerned about the water problem, so I bought a small cabin with gravity fed spring water and wood burning stove."

One respondent returned the survey but did not complete it, noting on the first page that the survey was 'not applicable - have own well.' Several respondents left attitudinal questions blank and noted 'private well' or 'own well' in the margins, with the implication being that because they have an individual source, these questions about managing water were not relevant to them. Several respondents also noted specifically that metering was not relevant or not feasible for anyone not on a public water source.

Given these responses, it is quite possible that other potential respondents had a similar reaction, but they did not reply at all to the survey request because they viewed it as irrelevant to them. These data reflect a lack of understanding among those with an 
individual source that all water is hydrologically connected and is a CPR and therefore management and conservation efforts do pertain to them.

To further explore the relationship between domestic water supply source and water conservation attitudes, we employed probit equations to estimate the likelihood of either agreeing or strongly agreeing to the survey statements featured in Table 3. The probit results (Table 4) show that age increases the likelihood of agreeing that water conservation should be voluntary and decreases the likelihood of agreeing to metering, suggesting that older individuals may view water more as a private property resource. However, the older the individual is, the more likely they are to agree that local officials should have final authority over water policy, suggesting some support for governmental control. Female respondents are more likely to favor metering water and paying a fee during droughts than males. Additionally, individuals with professional or graduate degrees are more likely than those with a high school diploma or less to agree that water should be metered, that during droughts individuals should pay a fee and that local officials should have final authority. All other levels of education are not statistically different than individuals with high school education or less. Finally, the higher the respondent's income the more likely they are to agree that public money should be used to develop or acquire new water sources and that local officials should have the final say in water policy.

The probit results follow the same patterns shown in Table 3 for the influence of the water source supply. Using private wells as our excluded category, we find that individuals with a municipal water supply are less likely to agree that water conservation should be voluntary or that their current supply is sufficient for their use. Individuals on municipal water, however, are more likely to agree that public money should be used to acquire new water sources, that water should be metered, that local officials should have final authority and that during droughts a fee should be paid on water use. Compared to individuals with their own well, individuals who are on shared wells are less likely to agree that their supply is sufficient to meet their use and more likely to agree that water should be metered and that during droughts a fee should be paid on water use. Finally, we find that when compared to individuals with their own wells, individuals with springs are less likely to agree they have a sufficient water supply and are less likely to agree that water use should be metered. These probit results suggest that both demographics and water source play a role in attitudes towards water management and conservation.

\subsection{Attitudes toward the role of government in water management}

As displayed in Table 1, there is a general lack of support for government involvement in water management. Those with an individual water source are especially reluctant to support measures perceived as impinging on their individual management authority (Table 3). Qualitative comments included on returned surveys provide additional depth to making this distinction. Of these comments, 61 were about government involvement in water management with most concluding that less government is better. Additionally, 14 people explicitly noted that government should have no role in water management on private property. Representative examples include:

For persons who own their land and use private wells or springs on their own property...If wells and springs are maintained properly - commissioners and government should leave them alone!! Most of mountain people who have had access to their own water supplies have knowledge needed to protect and maintain these water sources. We have for years. Most of 


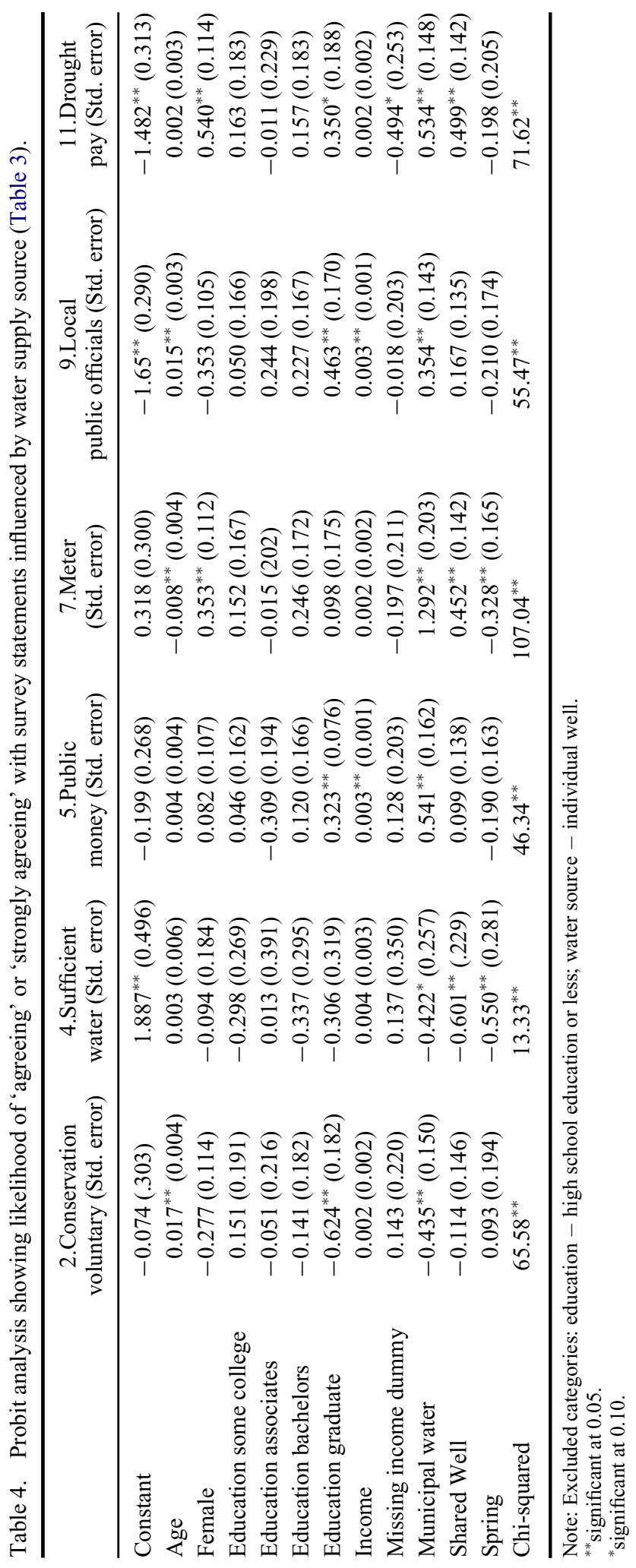


problems are in town and city supply. Persons with private water supplies should NOT have to pay for town.

I don't think that people who have springs or private wells should have to pay any 'water fees' because these people have paid to have a well dug or maintained their spring. The gov or county isn't going to pay for things that stop working e.g. well pump. I conserve my water and I don't want co/state/gov telling me how much water I can use.

My well gives pure, good water. I take care of my family's water needs. I resent it when anyone says I have to pay for THEIR water needs, or when they try to regulate my land use for THEIR benefit.

I personally take water conservation seriously. I also strongly believe that water that originates on my property is mine to manage and use. That it is not the role of the federal government to claim jurisdiction over any water that originates on private land. This also includes state or local government as well. The private land owner has an obligation to protect his $\mathrm{H} 20$ supply and manage it in a responsible manner.

There was a single comment relevant to sharing a well, where the respondent noted that the survey, "does not consider residents who share wells in neighborhoods w/ POAs [property owners associations]. I pay one flat fee for my water (annual). Testing, maintenance and treatment conducted by POA - contracted out. As a single person, flat rate is same for me as it is for families. They have more to laundry, wash, cook (more water use). I feel water fees should be set accordingly."

There were no similar comments made relevant to municipal supplies. However, 20 respondents did express concern about growth in the municipal areas and/or with the local university and the resulting increased strain on the water supply. These responses may reflect some sense of understanding that water use by one entity (e.g. a city) potentially affects others. The comments, however, do not seem to reflect an understanding that the cumulative impact of many individual wells may also affect the water supply.

\subsection{Perceptions of the physical water supply}

The survey asked respondents if the amount of water available to their community had increased or decreased in the past 10 years, or was expected to change in the next 10 years. Respondents with springs were most likely to say that there is less water available now than 10 years ago and least likely to say that they did not know whether available water had changed (Table 5). Looking to the future, those with shared wells or springs are much more likely to express uncertainty about future water availability. When asked where they receive information about their water source, those with springs were most likely $(62 \%)$ to say that they monitored their source personally. Therefore, these respondents are likely more familiar with the flow of their spring and know its history and/or variability and hence are less comfortable predicting future conditions. Conversely, half or more of respondents with individual or shared wells reported that they do not receive information about their supply from any source. Although neither of these groups claim to be well informed, those with shared wells are more likely to say that they do not know about water conditions, past or future. This may reflect recognition that they do not have sole control over the use of their source and this increases the uncertainty. Not surprisingly, $61 \%$ of those on a municipal supply report that their utility is the primary source for information. Those on municipal supplies, who report an expectation for more future water availability, may reside in communities with recently 
Table 5. Percentage of respondents indicating the status of their water supply in the past 10 years and predicting the status for the next 10 years.

\begin{tabular}{|c|c|c|c|c|c|c|c|c|}
\hline \multirow[b]{3}{*}{$\begin{array}{l}\text { Water } \\
\text { source }\end{array}$} & \multicolumn{8}{|c|}{ Perception of water supply* } \\
\hline & \multicolumn{2}{|c|}{ No change } & \multicolumn{2}{|c|}{ More water } & \multicolumn{2}{|c|}{ Less water } & \multicolumn{2}{|c|}{ DK } \\
\hline & $\begin{array}{c}\text { Past } \\
10 \text { years }\end{array}$ & $\begin{array}{c}\text { Next } \\
10 \text { years }\end{array}$ & $\begin{array}{c}\text { Past } \\
10 \text { years }\end{array}$ & $\begin{array}{c}\text { Next } \\
10 \text { years }\end{array}$ & $\begin{array}{c}\text { Past } \\
10 \text { years }\end{array}$ & $\begin{array}{c}\text { Next } \\
10 \text { years }\end{array}$ & $\begin{array}{c}\text { Past } \\
10 \text { years }\end{array}$ & $\begin{array}{c}\text { Next } \\
10 \text { years }\end{array}$ \\
\hline Municipal & 32 & 22 & 6 & 11 & 22 & 31 & 40 & 36 \\
\hline Shared well & 39 & 25 & 2 & 4 & 13 & 27 & 45 & 45 \\
\hline Private well & 36 & 25 & 5 & 2 & 23 & 34 & 36 & 39 \\
\hline Spring & 35 & 22 & 6 & 1 & 36 & 33 & 23 & 46 \\
\hline
\end{tabular}

Note: chi-square ${ }^{*} p<.01$.

acquired water supplies and, as a result, receive information indicating an increased future water supply. The expectation may also reflect confidence in the utility to ensure that more water is available to serve increased demand.

\subsection{Paying for public conservation measures}

To further explore the influence of a respondent's water source on their attitudes about water management, we developed a contingent valuation scenario on a county-wide water conservation program. Although this scenario is plausible, it is not based on any actual proposed policy in this region. Respondents were given this statement:

Suppose that to implement water conservation measures county residents would pay a onetime payment of $\$ A$ per household in higher county taxes. The money would be used to provide rebates to residents for the purchase of low flow toilets or rain barrels to help save water at home. The money would also be used to re-vegetate creek banks and install permeable pavement where feasible. These measures reduce runoff from storms and help with recharging the groundwater supply. The goal of the program is to provide more water security in the county and to ensure a more stable water supply that can ease stress during droughts. Suppose that this proposal to approve the tax and provide conservation measures will be on the next election ballot. Remember, if the proposal passes you would make a onetime payment of \$A in higher taxes and you would have \$A less to spend on other things. Also remember that if the referendum passes the conservation measures would be implemented and more water would be available in your county during times of drought.

Within the survey, $\$ A$ took on the randomly assigned values of $\$ 5, \$ 20, \$ 40, \$ 80$ or $\$ 150$. We asked respondents how they would vote on this proposal with three choices FOR, AGAINST or DON'T KNOW. One problem that arises when coding dichotomous choice contingent valuation questions is how to address 'don't know' responses. We follow the conservative approach and code all 'don't know' responses as 'no' responses (Groothuis and Whitehead 2002; Caudill and Groothuis 2005).

In the contingent valuation scenario, the qualitative variable yes is equal to one if the respondent answered FOR. Table 6 shows four logit specifications on the likelihood of a yes response. In the first specification, we include only water source as an explanatory variable, in the second specification we include attitudinal dummy variables created from attitudinal questions in Table 1. Each dummy variable is coded as yes if the respondent either agreed or strongly agreed to the attitudinal question. The third specification 
Table 6. Determinants of Voting for Public Conservation Policy. Attitudinal statements 1-13 are in Table 1.

\begin{tabular}{lrrrr}
\hline Variable & $(1)$ & \multicolumn{1}{c}{$(2)$} & \multicolumn{1}{c}{$(3)$} & \multicolumn{1}{c}{$\left(4^{*}\right)$} \\
\hline Constant & $0.9725(0.00)$ & $-1.392(0.04)$ & $-1.535(0.03)$ & $-2051(0.05)$ \\
Log WTP Bid & $-0.386(0.00)$ & $-0.429(0.00)$ & $-0.437(0.00)$ & $-0.452(0.00)$ \\
Spring & $-0.436(0.12)$ & & $-0.108(0.74)$ & $0.076(0.82)$ \\
Shared well & $0.863(0.00)$ & & $0.547(0.03)$ & $0.423(0.11)$ \\
Municipal water & $0.750(0.00)$ & & $0.164(0.60)$ & $-0.006(0.98)$ \\
1. Conservation & & $0.323(0.14)$ & $0.333(0.13)$ & $0.300(0.19)$ \\
2. Voluntary & & $-0.651(0.00)$ & $-0.641(0.00)$ & $-0.586(0.01)$ \\
3. Growth & & $0.219(0.33)$ & $0.226(0.33)$ & $0.286(0.23)$ \\
4. Satisfied & & $0.662(0.15)$ & $0.752(0.10)$ & $0.759(0.12)$ \\
5. Public money & & $0.561(0.01)$ & $0.560(0.01)$ & $0.571(0.01)$ \\
6. Economy & & $-1.127(0.00)$ & $-1.153(0.00)$ & $-0.968(0.00)$ \\
7. Meter & $1.332(0.00)$ & $1.268(0.00)$ & $1.189(0.00)$ \\
8. Development & & $0.886(0.04)$ & $0.869(0.05)$ & $0.910(0.05)$ \\
9. Local & & $0.427(0.03)$ & $0.408(0.04)$ & $0.385(0.07)$ \\
10. State & & $-0.344(0.19)$ & $-0.324(0.22)$ & $-0.142(0.60)$ \\
11. Fee & & $1.06(0.00)$ & $1.01(0.00)$ & $0.910(0.00)$ \\
12. Enough water & & $0.075(0.72)$ & $0.053(0.80)$ & $0.136(0.55)$ \\
13. Drought & & $-0.160(0.46)$ & $-0.121(0.57)$ & $0.006(0.97)$ \\
Log likelihood & $-420.694(0.00)$ & $-336.459(0.00)$ & $-333.841(0.00)$ & $-318.627(0.00)$ \\
\hline
\end{tabular}

Note: $N=651$.

${ }^{*}$ Specification (4) includes controls for income ( + and significant), education dummies ( + and significant), gender (female + and significant), county (insignificant), home ownership (insignificant), and a missing income dummy ( - and significant). The missing income dummy variable controls for individuals who did not report their income in the survey.

includes both water source and the attitudinal dummies. The fourth specification includes demographic variables, as well as both the water source variables and attitudinal dummies.

We find that for the first specification, water source matters. Individuals who have either municipal water supply or a shared well are more likely to vote yes on a public conservation policy than individuals on a private well, which was the excluded category. Individuals with springs are not statistically different than individuals with their own wells. Our results suggest that people with their own well or spring perceive the resource as private, while individuals with municipal water or a shared well perceive the resource as collective.

Specification 2 includes only the attitudinal dummy variables. ${ }^{2}$ Respondents who either agree or strongly agree to the following attitudinal statements: 5 - Public money should be used to develop new water sources; 7 - It is important to meter water use; 8 Any development decision should include assessing the impact on water; 9 - Local public officials should have the authority to make water management decisions; and 11 During serious droughts I would support a one-time fee assessment, all are more likely to vote yes on the public water conservation proposal. We also find that respondents who either agree or strongly agree to attitudinal statements: 2 - Household water restrictions should be voluntary and 6 - In water planning, the health of the economy is more 
important than protecting the environment, are less likely to vote yes on the referendum on public conservation measures.

Specification 3 includes both water source and the attitudinal dummy variables. These results show that the influence of all attitudinal variables remain the same in sign and statistical significance, while the influence of water source becomes statistically insignificant for municipal water, but remains positive and statistically significant for respondents with shared wells. Our analysis suggests that once attitudinal differences are controlled, only individuals with shared wells are more likely to vote yes on a public conservation measure. This might indicate that individuals with shared wells experience (or fear) water scarcity more than respondents with a different water source. This aligns well with the results in Table 2 showing that shared wells are the least preferred of all sources and offers further support that these respondents may most thoroughly experience managing water as a CPR and find it unappealing.

Specification 4 includes water source, the attitudinal dummy variables and demographics for additional controls. The results reveal that the influence of attitudinal dummies does not change, but the influence of being on a shared well becomes statistically insignificant. When both attitudinal and demographic variables are included water source does not affect the probability of voting for public conservation measures. This suggests that water source influences people's attitudes towards water but does not influence the likelihood of voting yes directly.

Again, the qualitative comments written on the surveys offer additional insight. There were 34 separate comments made about the conservation tax question with most of these being short notes emphasizing their negative response by writing, 'NO' or a similar antitax sentiment. Among the more expansive comments, three expressed support for the idea; another six expressed support for conservation, but not necessarily a tax; five stated their lack of faith in government to implement such a program; seven expressed a reluctance to pay for others; and two stated it is irrelevant for those with their own well.

\section{Discussion/conclusion}

Overall, these data suggest that having an individual water source, rather than simply being an urban or rural resident, is a strong indicator of attitudes toward water management and conservation. Generally, those with individual wells or springs do not see themselves as integrated and/or affected by water management issues beyond their individual source. Subsequently, they are less likely to welcome government management and do not support paying fees or taxes to support water conservation or other management efforts. Many of these individuals do, however, express an awareness of the need for conservation and confidence in their ability to protect 'their' resource. Although they are also largely rural residents, those with a shared well align more closely with respondents on a municipal supply in showing a stronger sense of awareness of water being a shared resource. These groups are more likely to support various management measures, including paying for conservation approaches.

Further enforcement for the idea that views of water as a communal resource differ is developed in data demonstrating the unique attributes within the shared well group. This group is responsible for ensuring their own water supply, without maintaining the sole authority over this supply, providing these respondents with the most direct experience with CPR management. The lack of authority seems to generate a greater sense of uncertainty about their water source and water conservation. As a result, shared wells are the least popular water source. Of respondents with a shared well, 45\% would prefer an 
individual well. As evidence of general ideas in CPR management, regardless of location, our findings align with existing research on community water management efforts in the developing world. Vasquez (2013) found that urban residents in Guatemala preferred municipal and private water services and did not value community-managed systems. Harvey and Reed $(2006,370)$ find that community management is highly problematic and, "Just because a community owns a facility does not necessarily mean that it will acquire a sense of responsibility for its management, nor does it guarantee a willingness to manage or pay for its [operation and management]."

These results raise concerns about how successful attempts to manage water as a CPR might be in places where people perceive that water can be an individualized, private resource. Because there is little recognition that water is hydrologically connected across all users, those with individual sources are unlikely to support proactive, generalized programs to protect or ensure a future water supply at a community or regional scale. In rural areas, where a large proportion of the population relies on individual wells or springs as water sources, our data suggest that planners and policy-makers will likely face resistance to any non-voluntary conservation efforts. During times of high water, this is not a concern. In humid areas, there is often only intermittent pressure to reframe public perceptions about water resources, usually during drought conditions. As the population continues to grow, however, and water demand continues to increase, the perceived ability to segregate water into individual and public sources may pose serious consequences to water management and conservation efforts in this region. As Lewis and Popp $(2013,89)$ note, "If perception is not taken into consideration, there is a danger in creating policy or developing programs that are not compatible with stakeholder expectations or ecosystem function."

Even more specifically, our work supports the need for local and regional assessments of perceptions about, and attitudes toward, water management, as our results differ markedly from a national survey on public attitudes about water management and drought. Stoutenborough and Vedlitz (2014) found that among about 2600 respondents throughout the US, there was expressed support for local and state government to manage water resources and support for shifting water from rural areas to cities. Clearly, this is not the case in western North Carolina. The long history of anti-government attitudes undoubtedly contributes to the lack of support for government intervention in water quantity management. Additionally, the perception of water as an individual resource reflects a lack of understanding about water as a physical system, but well aligns with perceptions of private property rights and subsequent resistance to any government intervention in that arena. This may not be unique to this region, but may be characteristic of many rural areas. Our work suggests that further study into these distinctions is warranted.

\section{Acknowledgements}

This research was funded through a grant from the Appalachian State University Research Council grant URC-F12. This research was approved under the Appalachian State University Institutional Review Board. Thanks to Aaron Chapman for his assistance with creating Figure 1.

\section{Disclosure statement}

No potential conflict of interest was reported by the authors. 


\section{Funding}

The Appalachian State University Research Council [grant number URC-F12].

\section{Notes}

1. The price elasticity of demand is negative because of the inverse relationship between price and quantity demanded. The higher the absolute value of price elasticity, the more responsive consumers are to price changes; i.e. consumption falls more in response to a price increase the more elastic consumer demand is.

2. Mitchell and Carson (1989) suggest that understanding the attitude-behavior relation provides some indication of actual behavioral intentions; that is, when attitudes align with hypothetical behavior questions, hypothetical behavior is a valid indicator of actual behavior.

\section{References}

Adams, W.M., D. Brockington, J. Dyson, and B. Vira. 2003. "Managing Tragedies: Understanding Conflict over Common Pool Resources." Science 302 (5652): 1915-1916.

Borisova, T., and D. Adams. 2010. Public Opinion About Water Availability. Gainesville, FL: Institute of Food and Agricultural Sciences document FE845. University of Florida/IFAS Extension. http://edis.ifas.ufl.edu/fe845.

Borisova, T., J. Evans, M. Smolen, and M. Olexa. 2013. "Current and Future Water Availability: Public Opinion in the Southern United States." Journal of Extension 51 (1): 1RIB7. http:// www.joe.org/joe/2013february/rb7.php

Boxall, B. 2013. "Californians Want Water Issues Fixed But Not Enough to Pay for It." Los Angeles Times, 30 September.

Boyer, C.N., D.C. Adams, and T. Borisova. 2014. "Drivers of Price and Nonprice Water Conservation by Urban and Rural Water Utilities: An Application of Predictive Models to Four Southern States." Journal of Agricultural and Applied Economics 46 (1): 41-56.

Caudill, S.B., and P.A. Groothuis. 2005. "Modeling Hidden Alternatives in Random Utility Models: An Application to Don't Know Responses in Contingent Valuation." Land Economics 81 (3): 445-454.

Cockerill, K. 2010. "Communicating How Water Works: Results From A Community Water Education Program." Journal of Environmental Education 41 (3): 151-164.

Covitt, B.A., K.L. Gunckel, and C.W. Anderson. 2009. "Students' Developing Understanding of Water in Environmental Systems". Journal of Environmental Education 40 (3): 37-51.

Coyle, K. 2005. Environmental Literacy in America. Washington, DC: The National Environmental Education and Training Foundation.

DeLorme, D.E., S.C. Hagen, and I.J. Stout. 2003. "Consumers' Perspectives on Water Issues: Directions for Educational Campaigns." Journal of Environmental Education 34 (2): $28-35$.

Evans, J., J. Calabria, W. Brown, A.M. Keyes, and M. Risse. 2011. Water Issues in Georgia: A Survey of Public Perceptions and Attitudes about Water. Athens, GA: Carl Vinson Institute of Government, University of Georgia Cooperative Extension. http://extension.uga.edu/publica tions/detail.cfm?number=B1385

Ewing, M.S., and T.J. Mills. 1994. "Water Literacy in College Freshmen: Could a Cognitive Imagery Strategy Improve Understanding?" Journal of Environmental Education 25 (4): $36-40$.

Gaffin, D.M., and D.G. Hotz. n.d.. A Precipitation and Flood Climatology with Synoptic Features of Heavy Rainfall across the Southern Appalachian Mountains. Morristown, TN: National Weather Service Weather Forecast Office. http://www.srh.noaa.gov/mrx/research/climo/ pcptxtnwd.php.

Groothuis, P.A., and J.C. Whitehead. 2002. "Does Don't Know Mean No? Analysis of 'Don't Know' Responses in Contingent Valuation Questions." Applied Economics 34 (15): 1935-1940.

Hardin, G. 1968. "The Tragedy of the Commons.” Science 162: 1243-1248. 
Harvey, P.A., and R.A. Reed. 2006. "Community-Managed Water Supplies in Africa: Sustainable or Dispensable?" Community Development Journal 42 (3): 365-378.

High Country Council of Governments (HCCOG). 2010. High Country Water Resource Plan. $\mathrm{http} / / /$ www.regiond.org/FINAL_WATER_RESOURCE_PLAN.pdf

ITT. 2012. Value of Water Survey: Americans on the U.S. Water Crisis. http://www.xyleminc.com/ valueofwater/report/index.html\#overlay $=$ cover\&page $=1 \&$ question $=01 \&$ panel=navigation .

Kenney, J.F., N.L. Barber, S. Hutson, K.S. Linsey, K. Lovelace, and M.A. Maupin. 2009. Estimated Use of Water in the United States in 2005. US Geological Survey Circular 1344. Reston, VA: US Department of the Interior. http://pubs.usgs.gov/circ/1344/

Kenney D.S., C. Goemans, R. Klein, J. Lowrey, and K. Reidy. 2008. "Residential Water Demand Management: Lessons from Aurora, Colorado." Journal of the American Water Resources Association 44: 192-207.

Lewis, S.E., and J.S. Popp. 2013. "Public Perception of Ecosystem Integrity of an Ozark Watershed." Journal of Soil and Water Conservation 68 (2): 89-98.

Mahler, R.L., R. Simmons, and F. Sorensen. 2005. "Public Perceptions and Actions Towards Sustainable Groundwater Management in the Pacific Northwest Region, USA." Water Resources Development 21 (3): 465-472.

Mahler, R.L., R. Simmons, F. Sorensen, and J.R. Miner. 2004. "Priority Water Issues in the Pacific Northwest." Journal of Extension 42 (5): 5RIB3. http://www.joe.org/joe/2004october/rb3.php.

Mitchell, C.M., and R.T. Carson. 1989. Using Surveys to Value Public Goods: The Contingent Valuation Method. Washington, DC: Resources for the Future.

Morton, L.W., S.S. Brown, and J. Leiting. 2007. Water Issues in the Four State Heartland Region: A Survey of Public Perceptions and Attitudes about Water. Iowa, Nebraska, Kansas, Missouri: Heartland Regional Water Coordination Initiative, http://www.soc.iastate.edu/extension/pub/ tech/SP289.pdf.

Noga, J., and G. Wolbring. 2013. "Perceptions of Water Ownership, Water Management, and the Responsibility of Providing Clean Water." Water 5: 1865-1889.

North Carolina State Board of Elections. 2014. Election Data. http://www.app.sboe.state.nc.us/ webapps/voter_stats/results.aspx?date $=02-01-2014$.

O'Gorman, P., and T. Schneider. 2009. "The Physical Basis for Increases in Precipitation Extremes in Simulations of $21^{\text {st }}$ Century Climate Change." Proceedings of the National Academy of Sciences of the United States of America 106 (35): 14773-14777.

Ostrom, E., J. Burger, C.B. Field, R.B. Norgaard, and D. Policansky. 1999. "Revisiting the Commons: Local Lessons, Global Challenges." Science 284: 278-282.

Pumphrey, R.G., J.A. Edwards, and K.G. Becker. 2008. "Urban and Rural Attitudes Toward Municipal Water Controls: A Study of a Semi-Arid Region with Limited Water Supplies.” Ecological Economics 65: 1-12.

Ray's Weather Center. n.d. Accessed 5 August 2015. http://www.booneweather.com

Responsive Management. 2003. Understanding the Georgia Public's Perception of Water Issues and the Motivational Messages to Which They Will Respond: Focus Group Findings. Harrison, VA: Georgia Department of Natural Resources. http://www.responsivemanagement.com/down load/reports/GAWaterFG.pdf

Seager, R., A. Tzanova, and J. Nakamura. 2009. "Drought in the Southeastern United States: Causes, Variability over the Last Millennium, and the Potential for Future Hydroclimate Change." Journal of Climate 22 (19): 5021-5045.

Shepardson, D.P., B. Wee, M. Priddy, L. Schellenberger, and J. Harbor. 2007. "What is a Watershed? Implications of Student Conceptions for Environmental Science Education and the National Science Education Standards.” Science Education 91 (4): 554-578.

Smakhtin, V.U., and E.L.F. Schipper. 2008. "Droughts: The Impact of Semantics and Perceptions." Water Policy 10: 131-143.

Sohn, J. 2011. "Watering Cities: Spatial Analysis of Urban Water Use in the Southeastern United States." Journal of Environmental Planning and Management 54 (10): 1351-1371.

Stoutenborough, J.W., and A. Vedlitz. 2014. "Public Attitudes Toward Water Management and Drought in the United States." Water Resource Management 28: 697-714. doi 10.1007/ s11269-013-0509-7.

US Census Bureau. 2010. People Quick Facts. Accessed 10 February 2014. http://quickfacts.cen sus.gov/qfd/states/37/37189.html 
US Census Bureau. 2014. American Community Survey. Accessed 6 February 2014. http://www.cen sus.gov/acs/www/

US Environmental Protection Agency. 2014. Surf Your Watershed. Accessed 17 February 2014. http://cfpub.epa.gov/surf/locate/index.cfm

Vasquez, W.F. 2013. "An Economic Valuation of Water Connections Under Different Approaches of Service Governance." Water Resources and Economics 2-3: 17-29.

Williams, J.A. 2002. Appalachia: A History. Chapel Hill, NC: The University of North Carolina Press.

Zetland, D. 2011. The End of Abundance: Economic Solutions to Water Scarcity. endofabundance.com 